\title{
Market design in Chinese market places
}

\author{
Barbara Krug • Hans Hendrischke
}

Published online: 26 August 2010

(C) The Author(s) 2010. This article is published with open access at Springerlink.com

\begin{abstract}
The market design (MD) approach to institutional analysis provides the analytical tools to evaluate endogenous institution building in local market places irrespective of the institutional setting of the national economy. Implicit in this analysis of endogenous institution building at the market place level is the recognition of institutional diversity, which none of the conventional forms of institutional analysis can provide. We extend the MD approach from its original game theory perspective to examine three market places in China: township and village enterprises, equity joint ventures, and public utilities. We conclude that the MD approach (1) provides the analytical tools and criteria to evaluate whether or not market places are robust and sustainable, (2) links market behavior at the market place level, which is characterized by size, coordination, and trust problems, with general level considerations based on transaction costs, and (3) suggests that functioning market places are achievable, even if the formal institutions of the general economy are weak or partially missing. Our research has policy implications and opens new avenues for research into the emergence of markets.
\end{abstract}

Keywords International business $\cdot$ China $\cdot$ Market design

The purpose of this paper is to apply market design (MD) as a "new" approach that focuses on localized institution building through examining the interaction between

This paper benefited from discussions at the Annual Meetings of the European Public Choice Society 2010 and EGOS 2010, and at a research seminar at the Faculty of Applied Micro-Economics and Organization, J. W. Goethe University, Frankfurt, Germany. Special thanks are due to Max Boisot, Bruno S. Frey, and Richard Whitley for their insistence on conceptual precision. Finally, we thank Mike Peng and three anonymous reviewers for their valuable comments and encouragement.

B. Krug $(\bowtie)$

Rotterdam School of Management, Erasmus University, Burgemeester Oudlaan 50, 3062 PA

Rotterdam, The Netherlands

e-mail: bkrug@rsm.nl

URL: http://www.rsm.nl; www.erim.eur.nl/chinabusiness

H. Hendrischke

Chinese Political Economy, School of Social and Political Sciences, The University of Sydney, 207A,

Old Teachers College (A22), Sydney NSW 2006, Australia

e-mail: hans.hendrischke@sydney.edu.au 
players within specific market places and identifying the conditions which sustain these market places independently from the general "rules of the game" of the larger economy. Our research questions address endogenous institution building: How are actors mobilized and sustained? Which endogenous institutions emerge from their interaction within local market places? As MD is rather new and as yet untested in management science, we will start by providing a short introduction to the approach of MD and by positioning it within the existing literature. We will then use three examples from China to evaluate the usefulness of this approach. We have chosen China because of the highly experimental nature of its economic reforms and because of its practice of testing institutional innovation within localized market places. In the final discussion we will elaborate on the extent to which the MD approach contributes to management science and in particular the institution-based view of the firm.

Markets differ widely with regard to the ways in which the general principles underlying market economies are realized. Comparative analysis has convincingly shown that similar principles, such as private property rights, rule of law, and flexible prices, can result in market economies as dissimilar as those of the United States and South Korea. Emerging market economies provide even more evidence that similar principles do not ensure similar market development (Whitley, 1999). Carney, Gedajlovic, and Yang's (2009) paper on the "varieties of Asian capitalism" (see also Redding \& Witt, 2009) shows that the diversity of economic systems in Asia reflects the "creativity" of firms, investors, and political agents in organizing business interactions through informal structures that operate in a localized way. In other words, there is not only diversity in markets at a national level, but also further diversity within those markets at a local, "market place" level. Within any given country the co-existence of functioning and illfunctioning local market places, either within the same sector but in different jurisdictions, or within the same jurisdiction but in different sectors, exposes the limits of any research which relies solely on an analysis of the overarching framework governing markets at a national level.

Markets also differ in regard to the organization of individual private exchange- the interactions that dictate how well they function. Williamson (1985) explains that the governance structure of a market can take any form between "hierarchy" (i.e., coordination by compliance) and "market" (i.e., the price mechanism). In this tradition the general claim that "institutions matter" becomes the empirical question "what is the requirement for the emergence, expansion, and stability of markets?" (Peng, Sun, Pinkham, \& Chen, 2009; see also Aoki, 2007). This change in perspective, from overarching institutions to local market places, results in a new understanding of markets, as the expansion and stability of these market places depend on the individual decisions of numerous participants, rather than on the overarching institutions governing them at a national level. This raises new questions: What makes participation in a particular market place an attractive course of action for firms? Who is involved in creating and changing the rules governing interaction within a market place? How is the expansion of organized private exchange ensured or, alternatively, what hinders market places from developing? What determines the size and stability of larger markets (Aoki, 2001; Axelrod, 1984; Dixit, 2004)? 
Answering these questions is not merely an academic exercise that contributes detail to the institution-based view of the players within a market. The behavior and performance of individual firms depend inter alia on the kind of markets in which they operate (Williamson, 1991). Functioning markets offer incentives for firms to enter. Firms operating in functioning markets have incentives to contribute to improving the rules which govern the interactions within their markets. This does not mean that the formal institutional framework can be disregarded by market players. Institution building in individual market places may help to entrench formal institutions into the daily operations of firms, but there is also evidence showing that formal institutions are under-used in favor of informal ones (Nee, 1989, 2000; Nee \& Opper, 2010). By virtue of its focus on its local market place, the perspective of a firm (or more generally: a market player) necessarily privileges informal over formal institutions. Because firms contribute to both diversity and change, an understanding of the specific nature of the interaction processes that underlie a market place is vital for designing the organizational structure, strategic behavior, and type of investment best suited to that market place.

Local differences within markets have obvious consequences for international business and management research (Bhagat, McDevitt \& McDevitt, 2010). Rather than regarding formal institutions as given and informal institutions as supplementary correctives, we propose a more dynamic view of institutions which assumes that firms will interact with other players and will consider their strategies in the context of the local market place. The consequence of this view for corporate and managerial strategy is that firms entering into a particular market will have to be prepared to consider multiple local strategies within a single national market. For managers this means that, in addition to their commitment to formal institutions (Peng, 2003; Zhou \& Peng, 2010; see also Baron, 1995), they will also have to pay attention to local institutions that develop as a result of their interaction with local partners.

MD originates from theoretical experiments based in computer simulations that are aimed at achieving market clearance in individual markets - that is, in achieving interactions between players that result in a functioning market capable of both attracting and retaining players. By focusing on market clearance, MD proceeds from a study of interaction and not from defined players: interaction creates or mobilizes the players required to sustain it. The general intention of $\mathrm{MD}$ is therefore to formulate the factors that enable market clearance within a defined market place. We propose to extend this approach to the institutional analysis of local market places or, more generally, to the analysis of endogenous institution building at a local level.

\section{What is market design?}

MD developed as a response to requests from companies and industry-specific regulatory agencies looking for a better way to organize "auctions" or, as in the best known example, a better way to allocate internships for medical students (overview in Kittsteiner \& Ockenfels, 2006; Roth, 2007). MD in its original form applies game theory and computer simulation to interpret empirical data with a view to restructuring impeded private exchange into functioning market places. Provided there is sufficient data, MD proceeds by testing the systematic character of features 
identified through game theory iterations through repeated experiments. Experiments using computer simulation first assume standard economic behavior (i.e., rationality). If this assumption does not offer satisfactory results, the simulation proceeds to search for "effects" (i.e., non-standard economic behavior provided by experimental economics or organizational psychology) (Maskin, 2008). Ultimately, MD analysis aims to improve interaction in market places where "market failure" is diagnosed. For MD, a functioning market is achieved when "market clearance" occurs, in that each market player (such as a firm) has matching business partners and no incentive to search for better partners or opt for a different organizational/coordination mechanism (Kittsteiner \& Ockenfels, 2006).

In its practical application MD prescribes institutional configurations which are able to sustain functioning market places. Its reliance on empirical data and disregard for established market institutions does not mean that the MD perspective is not based on theory. By insisting that the strategic behavior of firms and their performance in a market place depend on micro-level institutions that evolve from the interaction of firms with other market players, the MD perspective is wellgrounded in institutional economics and the institution-based view of the firm. By way of summarizing empirical studies and identifying systematic factors enabling discrimination between functioning and ill-functioning markets, MD moves to a broader research agenda and more general results. It has formulated three requirements for functioning markets: institutional devices agreed upon in one market place must, at a minimum, be able to motivate a sufficient number of players ("thickness"); they must provide safe participation and interaction for these players; and they must achieve market clearance. We propose to apply this approach to the institutional analysis of local market places, or, more generally to the analysis of endogenous institution building (Figure 1).

\section{Positioning market design in the literature}

With its focus on interaction and its functional definition of market players, the MD perspective adds new insights to the dominant approaches for explaining institutional diversity and change in China (Keister, 2009), such as the sociological power conversion approach (Nee, 1989, 2000; Walder, 2003), the comparative business system approach (Carney et al., 2009), and the institution-based view of the firm (Peng et al., 2009).

Figure 1 MD research trajectory

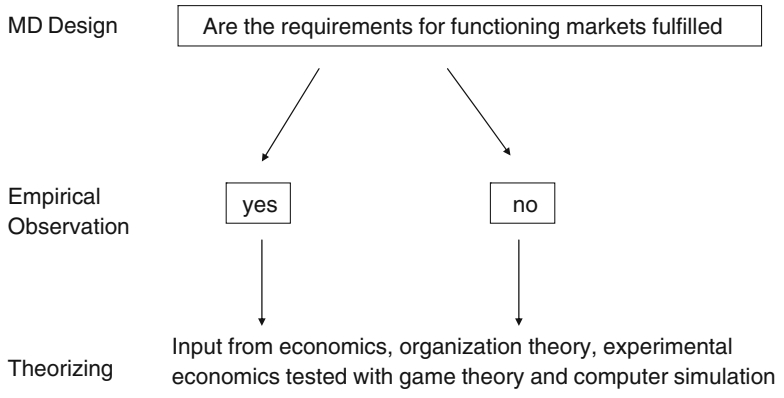


The power conversion approach argues that members of the former socialist political and administrative nomenclatura play a major role in creating diversity and change, through the separation of political leadership (initiating institutions) and bureaucracy (implementing institutional constraints and change), and their retention of control over assets. While this political analysis is useful for cross-country comparison, it fails to explain differences in the behavior of the political leadership or bureaucracies within one country. In China, for example, we find that in some localities the political leadership and bureaucracy succeed in retaining control over the assets and cash flow of firms, while in other localities they encourage private exchange and even embark on complementary infrastructural investment and asset protection. There is therefore a need to disaggregate the state (as stressed already in the in the Grabbing Hand versus Helping Hand controversy-Frye 2002; Frye \& Shleifer, 1997). This has been done through studies that analyze the influence of the communist party on corporate governance of stock-listed companies (Opper, Wong, $\& \mathrm{Hu}, 2002$ ), central-local fiscal relations (Wong \& Chai, 2000), and the emergence of patronage systems between local government agencies and local firms (Walder, 1995). While these studies point to institutional weaknesses and severe agency problems of the central state (Hendrischke, 2007; Krug \& Polos, 2004), they yield few positive results in terms of explaining elite behavior beyond arbitrary self interest (Nee, 2000).

From the MD perspective these political issues are examples of competing institutions leading to fiscal federalism and local autonomy through the decentralization of decision-making power and the transfer of resources to local administrative units. From this perspective, diversity of markets reflects decentralization rather than agency problems (Qian \& Weingast, 1997; Weingast, 1995). The MD perspective draws attention to how the decentralized local market places generate coordination mechanisms. The best-known example of such crucial localized institution building is taxation, where local administrative units negotiate the total amount of revenue to be collected on behalf of the national tax office, or agree on a sharing ratio in so-called tax contracts.

The MD approach is less concerned with a general notion of effective government than with the institutional capacity of political and administrative agencies in structuring specific markets. MD argues that, as elements of endogenous institutional change, firms come to terms with bureaucratic control, patronage, or an "arm's-length" state, and they do so to different degrees across industries and localities, and even to differing degrees within one locality or industry. MD suggests that the political leadership or bureaucracies have to be seen not only as regulators but as active market players, whose influence is defined by their interaction in the market. Ultimately the influence of the political leadership and bureaucracies is limited by the "economic power" of firms, including the mobility of their assets in terms of their ability to move operations to other market places (which could be other sectors or localities). From this perspective both the private sector and local government agencies are motivated to align the interests of all players in search of a suitable local market design and favorable local institutions. While the exit option granted by the mobility of the firm's assets may constrain the "predatory" local state, and compliance with the formal institutional frame may set benchmarks, the fact that firms derive their comparative advantage from negotiation with local government agencies contributes to a diversity of local market places and local business 
environments. For MD the observed iterative processes of bureaucratic coordination, patronage, even the use of price control and social mechanisms, are part of local institution building among market players.

The comparative business system approach to explaining differences between market economies has proceeded from a focus on national business systems and problems of stability, transition, and convergence to an inclusion of internal differences in national economies, which brings it closer to the MD perspective. From analyzing structures (Whitley, 1999), isomorphism (institutional theory-Clegg \& Redding, 1990; DiMaggio \& Powell, 1983; Selznick, 1996), or transaction costs (North, 2005; Williamson, 1985) in the comparative business system approach, Carney and colleagues (2009) have extended the varieties of capitalism approach to include endogenous change in their analysis (see DiMaggio, 1988; Hall \& Soskice, 2001) with firms actively contributing to institution building. For example, in relation to China, the varieties of capitalism approach suggests that firms organize market surrogates in the form of business groups or networks to fill "institutional voids" (Redding \& Witt, 2009) and thereby contribute to co-evolutionary processes.

The MD approach takes this analysis one step further by empirically observing how firms fill institutional voids beyond the varieties of capitalism focus on interfirm relations and their limited impact on institution building. The MD approach, for example, includes political leaders and local administrations in its analysis, if these are found to act as market players in a local market place. This enables the MD approach to differentiate between different forms of market participation which reflect interfirm behavior as well as effects of asset ownership or control rights by the (local) state. The MD approach, finally, is able to specify "endogenously" generated forms of transaction costs in form of the costs of coordinating exchange and aligning the interests of business partners.

Concerning the institution-based view of the firm, the MD approach proposes a specific perspective on the connection between institutions and firms (see also Peng, 2003). The conventional institution-based view regards institutions as exogenous and gives informal institutions a supplementary and subordinate role to the dominating formal institutions. The MD perspective draws attention to the alternatives to formal institutions. Whether the alternatives are called informal (Hendrischke \& Krug, 2010) or are assumed as being culturally determined (Clegg \& Redding, 1990; Hamilton, 2006) is of little concern to the MD perspective. Instead, the MD perspective observes that interaction in a specific market place can substitute formal institutions with informal institutions in response to the demand from market participants for more effective constraints and incentives.

In summary, the MD perspective is based on an endogenous institutional analysis of market places. It provides the analytical tools and criteria to evaluate whether or not market places are robust and sustainable. Implicit in this approach is recognition and justification of institutional diversity, which none of the conventional forms of institutional analysis can provide. The justification of diversity lies in the nature of institution building through interaction by all market participants under specific local conditions. At first glance, this endogenous process of building market places and their requisite institutions seems to go against the grain of what is expected from institutions. In contrast to the general assumption that a formal institutional framework is necessary to implement market conformity at the localized, market place level, MD 
suggests that market conformity is achievable at the local level even under weak or missing formal institutions. The transition from local-level market adaptation to national-level market conformity within both expanding markets and a national institutional framework is not within the focus of this paper but will be taken up in the discussion.

Applying market design to the Chinese markets

An economic explanation and justification of institutional diversity is currently lacking for China's experimental economic reforms. Below we will present three examples of how the MD perspective can produce new insights into both successes and failures within the Chinese reform processes. The MD criteria for the emergence of well-functioning markets translate into three questions: (1) How can a sufficient number of economic players, who are willing and able to interact in a market place, be mobilized to become market players (the requirement of "thick" markets)? (2) How can sufficient trust be generated among all market players to sustain their participation (the requirement of safe participation)? (3) How can market participants be matched to ensure market clearing at explicit or implicit relative prices, and what coordination mechanism is needed to let demand meet supply (the requirement of effective coordination)?

Based on these three requirements for functioning markets (thickness, safe market participation, and market clearance) we will first turn to a functioning market as a starting point for inquiring how market players meet these requirements. The example of township and village enterprises (TVEs) below shows that a combination of MD considerations and the institution-based view of the firm offers an insightful interpretation. We then turn to two markets known for their ill-functioning: the market for equity joint ventures (EJV) and the Chinese market for public utilities. We chose these examples to illustrate two different causes for ill-functioning: while both cases show that one or more of the MD requirements were not met, the underlying dynamics differ. In the case of EJVs, a combination of insights into nonstandard economic behavior from experimental economics and institutional analysis allows identification of a time coordination failure. The example of the public utilities market shows that a combination of the power conversion approach (see above) with institutional analysis points to a coordination failure within the state administrative hierarchy. Both cases draw attention to the shortcomings of standard approaches, which emphasize politically-initiated formal market institutions and fail to include government agencies as market players in their analysis (shortcomings also observed by Peng et al., 2009). We hope these examples will encourage further research into China's dynamic institutional setting as a natural experiment site where well-functioning and ill-functioning markets co-exist.

\section{The emergence of functioning markets}

The start of China's transformation from a socialist economy to a market economy, led by local market places, was not a foreseen development of Chinese economic reforms (World Bank, 1995). One of the most surprising features of this 
transformation was the emergence of local firms under "collective ownership" which were able to initiate and thrive under market competition (Huang, 1990; Jiang \& Hall, 1996; Kung, 1993; Li, 2005). The overall economic performance of these socalled TVEs, and of private entrepreneurship in the 1980s, was strong enough for them to become the engine of growth in the 1990s and the major source for tax revenue and export earnings in the following decade. This led to the rapid expansion of a private sector characterized by a competitive market.

This development seems to contradict the tenet of conventional institutional theory (inspired by North, 2005), that private property rights and the rule of law are prerequisites for market economies. We will show that empirical data point to deficiencies in institutional concepts while supporting the need for institutional analysis.

In transition economies the emergence of markets starts with the re-emergence of private exchange. While private exchange is a universal phenomenon which is hard to suppress and is compatible with all economic regimes, the emergence of markets is not. In formerly socialist economies private exchange, in particular firm-to-firm business interaction, is burdened with a liability of newness which needs to be mitigated by legitimation (Grabher \& Stark, 1997; Milgrom, North, \& Weingast, 1990 ) in order for individuals and firms to become empowered as economic actors. Only then are they able to overcome their subordinate status of implementing state regulation or quota. In contrast to other transition economies, the empowerment of China's firms was not dependent on private property rights. Instead Chinese reforms started with a "gift" in the form of a widespread transfer of decision-making rights (and control) to local government agencies and from them to firms and individuals. Decentralization of administrative decision-making power within the state apparatus established a form of fiscal federalism (Qian \& Weingast, 1997; Weingast, 1995) which included discretionary power for local government agencies to control assets, including land use rights, combined with de facto rights to levy local taxes and local fees. The resulting jurisdictional tax competition introduced variations in local markets and impacted on the decisions of local firms in choosing where to expand their business. At the same time, the break-up of existing state-owned enterprises (SOEs) and decentralization of managerial decision-making powers, including the right to allocate resources, where and when to invest, and the right to claim residual profit (Hansman, 1996), turned existing managers into entrepreneurs and participants in a new market place. From an MD perspective, we can argue that the decentralization of decision-making rights and widespread transfer of the control of rights to individuals, firms, and local government agencies ensured the "thickness" of the new market place in terms of its opportunities for private exchange. In short, decentralization of decision-making rights to individuals, firms, and local government agencies form the first building block by which the three market requirements are met.

The decision of economic agents to take opportunities depends on whether there is safe participation in the market. One aspect of safe market participation refers to legitimation, which relies on social and political acknowledgement (Cucco, 2008; Goodman, 2008) and acceptance, if not legal protection, of private exchange, private investment, and entrepreneurship. Under the condition of unsafe market participation market players forego innovation, or refrain from revealing their true preferences and 
disclosing valuable information about business opportunities; economic exchange gets stuck in short-term and arbitrage dealings.

While guanxi, the personal relationship-based trust attributed to Chinese culture, does not survive empirical scrutiny (Clegg \& Redding, 1990; best critique in Goodman, 2007), more generic approaches have shown that trust depends on repeated interaction (Axelrod, 1984) and participation (Bohnet, 2006). Further, trust evolves, but also relies on rational decision-making, for example, when exchange partners agree on specific dispute settlement schemes (Güth \& Ockenfels, 2003). Trust can also be provided by social groups or guilds (Coleman, 1990; Greif, 1989; Hendrischke, 2007) and can be generated within a social frame (Greif, 1997) or via institutions and organizations (Nooteboom, 1996). Safe participation is not guaranteed by culturally driven trust.

The Chinese answer to the need for trust, legitimation, and ultimately safe market participation was to politically embed private exchange and investment. This constitutes our second building block for securing functioning market places. TVEs were an example of the predominance of locally-based political embeddedness over and above resource and industry-specific embeddedness. TVEs were not local state firms, but included an increasing number of private firms or mixed-ownership firms with a solid base of private investment. The sharing of collective and later registered ownership rights was their most prominent feature. By initially allocating ownership shares to local government agencies, incentives were created to protect assets and contracts, share political and market knowledge, and secure a favorable mix of taxation and regulation. Moreover, while the conventional analysis quite rightly stresses the transaction cost advantage of this type of firm (Krug \& Hendrischke, 2008), the MD perspective draws attention to the dynamic and iterative interaction that this form of embeddedness generates. With an increasing number of firms and private exchanges successfully operating in the new market places, and with increasing cases of "honest" and credible interactions, market participation became attractive for more cautious economic players.

Political embeddedness turns local government agencies into market players, as they are directly involved in market transactions, instead of only being the representatives and executors of formal institutions. In this environment of weak formal institutions the dominant coordination mechanism between market players are negotiations, which are the third building block for meeting market requirements. Negotiations can be an effective device for coordinating interaction in a market place. The combination of decentralization, political embeddedness, and the negotiation or exit options in the new market place turns the coordination challenge into a restricted non-cooperative game (Zhu \& Krug, 2007).

In this game, the business community and local government agencies, as the two dominant controllers of resources, share an interest in maintaining and increasing the value of local resources, from which they both profit. Each party has an incentive to increase the individually appropriable share of overall outcome. This can be done by (re-)investing in the local resource base and/or by unilaterally increasing the individual share to the detriment of the other partner. In this game, local state agencies expand their share of overall returns by raising taxes while firms play a role depending on their ability and willingness to threaten to leave a locality (exit) or to object through renewed negotiations (voice). Thus, both state agencies and firms 
have an incentive to settle for a solution, that is, to share local net returns in such a way that no partner can change strategy without hurting total outcome (known as the "equilibrium solution," see Greif, 1997; Zhu \& Krug, 2007). This game can be interpreted as an implicit contract which gives local firms operational autonomy and profit in return for workplace generation, tax revenue, and a broadening of the tax base. There is also an implicit contract about joint investment (and cost sharing) in the local resource base that goes beyond mere road building or communication. It includes innovation when private investment in $R \& D$ is accompanied by access to state-controlled research and is subject to tax breaks and other subsidies.

From the MD perspective, the emergence of a functioning market for TVEs was the outcome of collaboration between the local political leadership and firms. By offering both players incentives to join the market, by politically embedding new market-conforming firms at the local level, and by coordinating resources via ongoing negotiations, the disadvantages of missing private property rights and lack of contractual security were mitigated. However, the outcome was not a static equilibrium. In the 1980s TVEs were the organizational type that best fitted the Chinese market, while in the 1990s a change towards diversified ownership structures saw incorporated firms gradually take over what has now become a small- and medium-sized enterprise (SME) market. This organizational change points to the flexibility of localized institution building.

In summary, political embeddedness, decentralization of decision-making power, and ongoing negotiations were the three building blocks for the emergence and development of a functioning market for TVEs as they ensured thickness, safe market participation, and effective coordination. While this conclusion contradicts the view that private property rights, flexible prices, and competition are necessary prerequisites for the emergence of markets, the two approaches are not necessarily incompatible. The MD set of requirements can be interpreted as the necessary process that precedes the emergence of price competition, of the kind analyzed by conventional economics and management studies. Institutional incentives, not covered in the usual analyses of intended formal institutions, were used to mobilize market participation by generating trust and contract security by aligning the interests of the business community and local government agencies in what can be interpreted as a restrictive non-cooperative game.

Our next step in testing the explanatory value of the three MD criteria and the corresponding building blocks is to analyze cases of "market failure." For this we will first turn to the near-collapse of the EJV market in the foreign direct investment (FDI) sector.

\section{Coordination failure in the market for equity joint ventures}

As shown in Table 1, from the late 1990s the market for EJVs (and this applies equally to the much smaller number of cooperative joint ventures) shrank dramatically in favor of wholly foreign-owned subsidiaries. The standard explanation is that EJVs were an effective device through which to save on transaction costs, as Chinese partners would bring in valuable local market knowledge, political information, and connections (Huang, 2003) and that the switch from joint ventures to wholly foreign-owned subsidiaries points to better governance and effectiveness 
Table 1 China's foreign direct investment (utilized FDI).

\begin{tabular}{llllll}
\hline & Total & $\begin{array}{l}\text { Equity Joint } \\
\text { Ventures } \\
\text { Percentage (\%) }\end{array}$ & $\begin{array}{l}\text { Cooperative } \\
\text { Ventures }\end{array}$ & $\begin{array}{l}\text { Wholly Foreign-Owned } \\
\text { Enterprises }\end{array}$ & Other \\
\hline 1988 & Billion US\$ & 61.8 & 24.4 & 7.1 & 6.7 \\
1989 & 3.39 & 60.1 & 22.2 & 10.9 & 6.8 \\
1990 & 3.49 & 54.1 & 19.3 & 19.6 & 7.0 \\
1991 & 4.37 & 52.7 & 17.5 & 26.0 & 3.9 \\
1992 & 11.01 & 55.6 & 19.3 & 22.9 & 2.3 \\
1993 & 27.52 & 55.8 & 19.0 & 23.6 & 1.5 \\
1994 & 33.77 & 53.1 & 21.1 & 23.8 & 2.0 \\
1995 & 37.52 & 50.8 & 20.1 & 27.5 & 1.6 \\
1996 & 41.73 & 49.7 & 19.4 & 30.2 & 0.6 \\
1997 & 45.28 & 43.2 & 19.7 & 35.7 & 1.4 \\
1998 & 45.46 & 40.4 & 21.4 & 36.2 & 2.0 \\
1999 & 40.32 & 39.3 & 20.4 & 38.6 & 1.8 \\
2000 & 40.72 & 35.2 & 16.2 & 47.3 & 2.3 \\
2001 & 46.88 & 33.6 & 13.3 & 50.9 & 1.8 \\
2002 & 52.74 & 28.4 & 9.6 & 60.2 & 2.3 \\
$\ldots$ & $\ldots$. & & & & 76.3 \\
2009 & 90.03 & 19.2 & 2.3 & & \\
\hline
\end{tabular}

National Bureau of Statistics of the People's Republic of China (2008).

of formal institutions as measured by international rankings (Meyer, Estrin, Bhaumik, \& Peng, 2009).

Yet, throughout the 1990s, we observe a gradual shift in utilized FDI from EJVs towards wholly-owned foreign enterprises (see Table 1). The acceleration of this shift after 2001, following China's accession to the World Trade Organization, only confirms a trend already well underway in the previous decade. We therefore argue that, while this late rush out of EJVs is attributable to an external top-down change in the regulatory environment, the ongoing long-term trend was entrenched in the internal weaknesses of China's EJV marketplace (Voigt, 2008). Information offered by personal accounts of practitioners in China (Clissold, 2005; Walter \& Howie, 2006) suggests that the way in which market players rushed into the Chinese market, and the resulting major coordination failure, neutralized the (assumed) transaction cost advantage of EJVs.

EJVs form a market place where local government agencies and the local business community offer an operational base for foreign companies through a package of real estate, infrastructure, favorable tax and regulatory regimes, plus "tailored" supply chains inside or outside of special economic zones (Huang, 2003). International as well as domestic firms have ample incentives to search for partners (including local authorities) offering the best-fitting package. Yet, in the 1980s and 1990s, foreign companies "rushed in" to conclude deals before they could possibly 
have known the features of specific transactions and the alternatives to these transactions. Likewise, local government agencies searching for investors opted for early deals. The story of the EJV capital investment market in China is one of mismatches and premature business deals, as the number of failed joint ventures indicates. Though underrepresented in national statistics or official company reports, there is overwhelming anecdotal evidence describing this phenomenon (Clissold, 2005; Dickson, 2003; Walter \& Howie, 2006).

This phenomenon is known as an "unraveling effect," which in general refers to a situation where no agreement on entry time or "trading hours" coordinates market transactions. Market partners rush into decisions before all alternatives are known. Each match is concluded before the market is "opened" (i.e., before the crucial features of the product, the transaction, and the market partner are known). Subsequently, more prudent actors who spend time assessing the quality, professionalism, or trustworthiness of potential partners face only a "thin" market — and a high chance that they cannot find a matching partner, with the result that there is no market clearing. This insight from the MD perspective sheds new light on the failure of EJVs in China. While unraveling can occur anywhere (Bates, Greif, Levi, Rosenthal, \& Weingast, 1998; Milgrom et al., 1990; Roth, 2007), networking in China makes the effect even more prevalent. Each match generates hidden costs in the lock-in effect of networks, which in turn creates costs that are seldom accounted for when the first deal is concluded. Switching to another alternative, while not impossible, is costly, as it implies leaving the original network (or special economic zone). In addition to the usual factors identified with high transaction costs, such as sunk costs or scale economies in exploiting existing supply chains, there are costs generated by the specific form of interaction. The strength of the networks in facilitating market transaction becomes a liability when it comes to designing competitive functioning markets.

With regard to China, MD points to a weakness of networks in solving time coordination problems, as they prevent agreement on trading hours long enough to screen all business alternatives. Networks may pre-empt market transactions, requiring "intervention" in the form of an exogenous regulatory regime. In other words a well-functioning market needs to be engineered (Maskin, 2008). It is worth emphasizing that the MD analysis does not require state intervention. An appropriate regulatory regime could, for example, take the form of tradition-based trading hours as stipulated by local law, or agreed upon by "guilds" (Greif, 1997).

In summary, transaction cost analysis, which suggested that EJVs are the best fitting organizational form for aligning the interests of foreign investors and domestic firms in China, does not stand up to empirical scrutiny. The MD approach, however, can explain the shrinking usage of EJVs as an institutional market failure, pointing to the limits of network-based negotiation for solving coordination problems and to remedial action in the form of improved coordination.

\section{Failure to secure safe participation in the market for public utilities}

China has an impressive record of state investment in transport, telecommunications, water, and electricity which created the infrastructure (with the exception of water supply in the late 1990s) needed to sustain high economic growth rates. Starting in 
2002, after the costs to the environment and social costs in the form of corruption became apparent, China attempted to redesign its market for public utilities (see several issues of Caijing Magazine July-August 2007; World Bank, 2007).

From the perspective of market players, the utilities market is chaotic and riddled with local overcapacity, price dumping and protectionism, rent-seeking and strategic behavior, conflicting outcomes of so-called "solutions," national policies that are not implemented, local policies which run counter to national legislation, the collapse of the EJV market, and the partial withdrawal of FDI (for the best description of this, see Laffont, 2004). Leaving aside the sector-specific technical problems, the MD perspective directs attention to the role of contracts as a specific problem seldom found outside China (Richter \& Wellisch, 1996). Irrespective of the political regime, government contracts are seen as an effective coordination mechanism for aligning the interests of investors and producers with the state. Contracts in China are ineffective where they fail to allocate enforceable decision-making rights. This happens when the rights to decide on investment (and capacity), market entry requirements, and purchase prices are contested by regulatory agencies. These agencies can be those under the State Development and Planning Commission, local government agencies in charge of "smaller project," or non-state foreign or domestic investors whose equity entitles them to participation in management (Clarke, 2008). Transcending technical issues such as contractual stipulations, auditing procedures, or scale and scope of regulation, the resulting conflicts concern the general enforceability of contracts, specifically their effectiveness to create actual and enforceable entitlements for producers, investors, and operators (March, Schultz, \& Zhou, 2000). Under segmented and contested administrative authority, there are conflicts about dispute settlement procedures when investors and local producers dismiss regulation agencies and dispute settlement regimes on the grounds that these have no formal authority over competition policy, or when local agencies or central ministries insist on hierarchical rules and regulations for dispute settlements but lack local authority. To add to this, the central state regards infrastructure as part of the "public order" notion in the Chinese constitution and insists on the prerogative to nullify agreements ex post (see analysis in Peerenboom, 2005) through additional "amendments" or new regulations. Finally non-state producers and potential investors insist on court rulings in the form of arbitration or litigation.

Competition between the different regulatory regimes indicates a failure within the state administration to negotiate coordination between all agencies involved (World Bank, 2007). However, this diagnosis offers few solutions. In contrast, from the MD perspective the market for public utilities is characterized as lacking safe participation and therefore fails primarily because firms or private investors lack access to political embeddedness (Tyler, 1990). Unlike the regular corporate environment where firms face a structured set of government agencies, the public utility market suffers from contested authority and competing political agents. Settling on one contract partner exposes firms to the risk that their contracts lack legitimacy and cannot be enforced. The long-term nature and sunk costs of infrastructure investment compound the risk, as switching contract partners in order to correct initial misjudgments can be close to impossible (McNeil, 1978). In other words, the inability to politically embed contracts in the public utility markets makes market participation an unsafe strategy and leads to insecure participation and 
subsequent underinvestment. From a MD perspective, the solution therefore lies in decentralization combined with market incentives, and not in continued attempts at recentralization.

This case draws attention to another insight of MD in regard to China, namely that the under-usage of law is an institutional device and not an institutional weakness. Aligning the interests of market players through contracting is generally assumed to considerably lower the costs of switching partners or of adjusting terms of business relations. From the MD perspective the cause of the ill-functioning market for public utilities is not the weak formal legal system but the inability to utilize political embeddedness as the standard procedure for circumventing courts or law enforcement. Instead of ongoing negotiations with locally empowered market partners, players in this market face ongoing, inconclusive contests about decision-making rights and dispute settlement regimes.

\section{Analysis}

As shown in Table 2, our analysis indicates that functioning markets in China appear when sufficient incentives and market-specific institutions are introduced to make participation in a competitive market a promising strategy for firms. Negotiated participation, political embeddedness, and renegotiated contracts are identified as specific forms of interaction which ensure the fulfillment of the three requirements for functioning local market places. Our first example, the TVEs, raises a puzzling question. If interaction in the private sector follows the logic of a restrictive noncooperation game, why do not more, or all, markets in China follow the same logic? In response to this question, the two examples of market failure serve to illustrate the institutional obstacles in meeting the three requirements. In the case of the EJV market, non-rational behavior, in the form of rushing into the market and accepting the first offer of a business relationship, led to mismatches, and subsequent thinning out of the envisaged interaction through EJVs. In this instance, the requirement of thickness was not achieved. The example of the public utility sector illustrates a coordination failure as investors or producers face competing government agencies and unenforceable contracts, which does not constitute safe participation. The result is a lack of market clearance with parallel over-investment and under-investment, and the collapse of a market solution for this sector.

Table 2 Are the market requirements fulfilled?

\begin{tabular}{llll}
\hline & Yes & No case 1 & No case 2 \\
\hline Empirical domain & $\begin{array}{l}\text { Township and village enterprises } \\
\text { (TVEs) as initial stage of a } \\
\text { private sector }\end{array}$ & $\begin{array}{l}\text { Equity joint venture } \\
\text { (EJV) sector }\end{array}$ & Public utility sector \\
Interaction & $\begin{array}{l}\text { Negotiated participation } \\
\text { Political embeddedness } \\
\text { Renegotiated contracts } \\
\text { Restrictive non-cooperation game }\end{array}$ & Unravelling effect & Unsafe participation \\
& Thining out of the market & Coordination failure \\
\hline
\end{tabular}


Our analysis highlights the following findings for China: markets are designed by market players. The point to note here is that "market design" does not refer to a consensus by which market players agree upon a supplementary set of institutions. Instead, MD is an iterative process (i.e., a cooperation game) in which market players react to external constraints and the expected behavior of other market players. This finding calls for a dynamic view of market development, and a more differentiated picture of the role formal and informal institutions play in this process. From a MD perspective it is less important whether institutions are formal or informal than whether they are actually employed or not.

The local state is empowered and, in collaboration with the private sector, able to establish functioning markets. This finding makes a strong case for disaggregating the "Chinese state"-specifically, for functionally separating political leadership from administration and central leadership from local political leadership. Local government agencies defy easy assumptions about their role and behavior. Modeling local government agencies as neutral executors of stipulations formulated in the general institutional frame disregards the evidence that there is choice within the general institutional framework. To assume that local governments only function as regulatory agents is to overlook the fact that they are owners of valuable local assets with incentives to make the best use of local resources and therefore act as market players with self-interest in achieving allocation efficiency. In short, the findings call for a more differentiated view of the state and its scaled role in economic development and institutional change.

Diversity in the business environment is a manufactured diversity, reflecting different ways by which local market players respond to constraints and opportunities to align their interests. New, and maybe China-specific, is the observation that local state agencies are crucial for the emergence and development of new forms of competition and, more generally, business relations at market place level. Entrepreneurs and firms face an accommodating local administration which, instead of insisting on compliance with national legislation, facilitates organizational innovation at the firm level (successfully in the case of TVEs) and the switch to new forms of business relations (unsuccessfully in the case of EJVs). We know that diversity in markets can be based on exogenous factors such as resources and industry-specific factors as well as demographic, technical, or cultural factors. We find that diversity can likewise reflect collective local institutions which have sprung up endogenously, following a localized market logic of their own.

These findings call to mind numerous approaches in management science and corresponding analytical tools which could be fruitfully employed to further theorize on the outcome of the empirical analysis. Among others, the question of homogeneity or heterogeneity within the concept of institutional isomorphism (DiMaggio \& Powell, 1983), social embeddedness and networking, institutional void, transaction cost economics, and contract theory are obvious candidates for re-examining the empirical findings by extending the "database." The MD perspective invites such imports of different concepts. In the following section we will limit ourselves to discussing what the MD perspective adds to the three dominant streams in China-specific transition studies literature. Our discussion will clarify why we think that the MD perspective offers a fruitful addition to the power 
conversion (elite analysis) approach, comparative business systems analysis and, most importantly from our perspective, the institution-based view of the firm.

Discussion: How does MD add to three existing perspectives?

When considering how to contribute insights from MD to the literature on power conversion, comparative business system/varieties of capitalism, and the institutionbased view of the firm, we also query, more generally, our understanding of and our analytical tool kit for examining economic development, institutional change, and transition. When is an economy in transition and when has it arrived? We will start with the three approaches noting the overlap with some of the MD findings.

The power conversion approach acknowledges choice within the set of formal institutions. The approach identifies state agents such as the bureaucracy (e.g., Nee, 2000) and local government agencies (Li, 2005; Walder, 1995, 2003) as actors which use their choice to pursue their particular self-interest. Implicitly it is assumed that these interests explain the heterogeneity of the local (including sectoral) business systems. The empirical critique from the MD perspective is that the power conversion approach overemphasizes the negative consequences of political agents pursuing their self-interest to the point that heterogeneity seems to indicate a commitment or enforcement failure. We find that collaboration with the private sector can lead to functioning markets, provided such collaboration follows the market logic of restricted cooperation games. Our conceptual critique of these approaches is that they fail to specify such self-interest in institutional terms. The power conversion approach goes as far as saying that there are patron-clients relations (Krug, Jacobs, \& Belschak, 2004; Walder, 2003) or open organizational boundaries (Nee, 2000) between state-based political agents and the economy. The MD perspective puts the self-interest or discretionary power of these political agents into an institutional frame by showing that local government agents, as quasi-owners of local assets, can become market players in local market places. Once they share interests with local firms they become partners in searching for new ways, outside the state sector, to organize production and coordinate business relations. In other words, political agents can and will use their discretionary power for either maximizing returns from the local base or implement policy as allocated to them by superior administrative bureaus. Mostly they do both, depending on the specific opportunities and effective control from above.

The critique of the power conversion approach allows us to answer our first research question, namely which actors are needed for endogenous institution building. The MD perspective identifies actors as those in control of resources and assets with an interest in exploiting (and re-investing into) the local resource base and sufficient discretionary power to locally introduce new coordination mechanism as drivers of institutional change.

At first sight, the "varieties in capitalism" approach, with its focus on variations of business systems across countries, does not seem to overlap with our locallyfocused MD approach as they operate on different scales. Yet three core concepts, or building blocks, of the variety found in the varieties of capitalism literature support the MD perspective in explaining institutional change within and across market places. One is the agent-driven analysis which sees firms no longer as institution 
takers but as agents which contribute to the generation of comparative advantages (Carney et al., 2009; Hall \& Soskice, 2001; Whitley, 2007). A second building block is the notion of ongoing heterogeneity which prevails when there is a mismatch between new institutions and existing institutions. A third is the notion of specialization discussed by Beckert (2010). These notions are linked to our notions of institutional fit and embeddedness.

The MD perspective offers to this line of reasoning an explanation of the underlying process which defines institutional complementarities by arguing that institutional complementarities, or heterogeneity, are either negotiated or the outcome of ongoing experimentation. For example, how private firms fit into the overall economic system of a socialist market economy with national legislation, Five Years Plans, and a large state sector, has been negotiated at the local level long before private firms were acknowledged at the national level. The point to note here is that by acknowledging private firms, local government agencies claimed "complementarity" and bestowed legitimacy on a new form of business.

Legitimation via local government agencies also plays a role in the other cause for heterogeneity, namely searching for a "market" niche by techniques of organizational innovation which offer a competitive advantage, such as specializing on new products. The challenge for the new private business sector, or for that matter all transition economies, is to find new, market-conforming incentive and coordination mechanisms. As these new forms become less risky and more profitable, the more firms and other economic actors subscribe to them. Acknowledgment and protection by local agents is crucial for mobilizing risk-averse entrepreneurs and for quickly securing market thickness. Chances to find suitable business partners increase with the number of market players, which in turn secure better market clearing, thereby setting incentives for more firms and local government agencies to imitate these procedures. This snowball effect basically explains the expansion of the private sector in China.

The varieties in capitalism approach has changed with the emergence of distinctive types of Asian capitalist states and transition economies (Carney et al., 2009) and, from our perspective, new market designs. Different modes of organizing production and coordinating economic activities outside the state sector are seen as necessary steps toward the development of capitalist economies (Grabher \& Stark, 1997). The insights of this approach, in particular its insistence on heterogeneity, helps us to answer our second research question: what are the endogenous institutions which emerge in markets? These are institutions which facilitate the building up of complementary, innovative forms of production and organization which, in turn, rely on incentives to switch to new forms and the mobilization of a sufficient number of firms to become competitive.

The overlap between the MD perspective and the institution-based view of the firm is not hard to see (Peng, 2003). We claim that the MD perspective enriches and specifies core assumptions of the institution-based view best exemplified by the first propositions of Peng and colleagues (2009: 67):

Proposition 1 Managers and firms rationally pursue their interests and make strategic choices within the formal and informal constraints in a given institutional framework. 
The MD perspective is able to add to this its specifications of the given institutional framework: the given institutional framework is, foremost, the market place; and within the market place, managers and firms take part in defining local institutions, while making strategic choices within both formal and informal constraints of the general institutional framework. In addition the MD perspective allows us to go beyond the general assumption of bounded rationality when cases of non-standard economic behavior are identified. Also, Peng and colleagues (2009: 68) suggest:

Proposition 2 While formal and informal institutions combine to govern firm behavior, in situations where formal constraints are unclear or fail, informal constraints will play a larger role in reducing uncertainty, providing guidance and conferring legitimacy and rewards to managers and firms.

Here, the MD perspective adds the specification that local market institutions, below the formal/informal divide of market institutions, will at least in part make up for lack of clarity and uncertainty by involving firms in localized institution-building and conferring locally acknowledged legitimacy and locally secured rewards.

This link between formal and informal institutions reveals a deeper conceptual problem, which goes beyond existing approaches and relates to our third research question. We will conclude by discussing this third question: How does the emerging diversity and heterogeneity relate to existing formal and informal institutions of the larger economy?

\section{Conclusion}

In at least three ways, MD-based analysis contributes new insights to the existing literature, in particular to the institution-based view of the firm and related endogenous institution building (see also Nee \& Opper, 2010) and to concepts and theories of Asia management research (Bhagat et al., 2010).

First, the MD perspective provides analytical insights into how institutions work by identifying market-specific interactions within individual market places as the link between institutions and firms as well as other market players. Interaction within a market converts formal institutions into effective constraints and incentives, provided that the constraints and incentives enable market places to function in terms of the three criteria of thickness, safe participation, and market clearance. Where formal institutions are not able to fulfill this role specific local institutions, rather than unspecified informal institutions, will fill the void. Two points are important to note here as they differentiate MD from the conventional institutional perspective. From the MD perspective we do not deny that informal institutions may fill gaps in the array of formal institutions, but place much more weight on the ability of local institutions to address dysfunctional market places by securing the three criteria of thickness, safe participation, and market clearance.

Second, the MD perspective links market behavior at the market place level, which is characterized by size, coordination, and trust problems, with general level considerations based on transaction costs. We can demonstrate that there are functioning market places characterized by decentralization of economic decision-making power, 
political embeddedness, and ongoing negotiation within a national economy known to have missing property rights and a weak formal rule of law. From the MD perspective we argue that in such market places the national institutions do not take precedence (this would be the industrial system argument), nor do local institutions determine the institutional outcome (the socio-political argument). Instead by dynamically extending the MD perspective to include expanding local market places, we postulate that a new institutional mix will emerge endogenously and locally, in response to demand from the market players. In expanding local markets, these players would include increasingly higher levels of the administrative hierarchy.

Third, in contrast to the conventional assumption that formal institutions are necessary to mobilize market conforming behavior at the local level, the MD perspective shows that functioning markets are achievable, even if the formal institutions are weak or partially missing. The driving force behind such movement towards functioning markets is the motivation of firms and other actors to search for the best-fitting market partners and a form of interaction which ensures the best matches. Our research links the results of game theoretical MD with the literature on transition economies and emerging markets, which has only recently added the link between micro- and macro-level institutional change to its research agenda. Our perspective opens a new research trajectory by pointing to the endogenous demand for institutions and the resulting co-evolution of markets and institutions.

This is a wide field for detailed empirical enquiry which is guided on the one hand by a set of criteria for evaluating the sustainability of market places, and on the other hand by a much wider focus on institutional diversity, as we do not have to call upon limited macroeconomic models to justify and explain the existence of heterodox market structures. Our research indicates that heterodox market institutions can be expected to exist as long as there is endogenous demand for them at a local level and as long as the flexible rules of economic institution building persist as part of political systems.

Open Access This article is distributed under the terms of the Creative Commons Attribution Noncommercial License which permits any noncommercial use, distribution, and reproduction in any medium, provided the original author(s) and source are credited.

\section{References}

Aoki, M. 2001. Toward a comparative institutional analysis. Cambridge: MIT.

Aoki, M. 2007. Endogenizing institutions and institutional changes. Journal of Institutional Economics, 3 (1): $1-31$.

Axelrod, R. 1984. The evolution of cooperation. New York: Basic Books.

Baron, D. P. 1995. Integrated strategy: Market and non-market components. California Management Review, 37(2): 47-65.

Bates, R. H., Greif, A., Levi, M., Rosenthal, J. L., \& Weingast, B. R. 1998. Analytical narratives. Princeton: Princeton University Press.

Beckert, J. 2010. Institutional isomorphism revisited: Convergence and divergence in institutional change. Sociological Theory, 28(2): 150-166. 
Bhagat, R. S., McDevitt, A. S., \& McDevitt, I. 2010. On improving the robustness of Asian management theories: Theoretical anchors in the era of globalization. Asia Pacific Journal of Management, 27(2): $179-192$.

Bohnet, I. 2006. How institutions affect behaviour: Insights from economics and psychology. In D. de Cremer, M. Zeelenberg \& J. K. Murnighan (Eds.). Social psychology and economics: 213-237. Mahwah, NJ: Lawrence Erlbaum Associates.

Caijing Magazine (Finance and Economics). 2007. http://magazine.caijing.com.cn/2009/cjindex2007/, Accessed Jul. 7, 2010.

Carney, M., Gedaijlovic, E., \& Yang, X. 2009. Varieties in Asian capitalism: Toward an institutional theory of Asian enterprise. Asia Pacific Journal of Management, 26(3): 361-380.

Clarke, D. C. 2008. Legislating for a market economy in China. The China Quarterly, 191: 567-585.

Clegg, S. R., \& Redding, S. G. (Eds.) 1990. Capitalism in contrasting cultures. Berlin and New York: de Gruyter.

Clissold, T. 2005. Mr. China. New York: HarperCollins.

Coleman, J. S. 1990. Foundations of social theory. Cambridge: Harvard University Press.

Cucco, I. 2008. The professional middle classes: Management and politics. In D. S. G. Goodman (Ed.). The new rich in China: 148-167. London: Routledge.

Dickson, B. J. 2003. Red capitalists in China: The party, private entrepreneurs, and prospects for political change. New York: Cambridge University Press.

DiMaggio, P. J. 1988. Interest and agency in institutional theory. In L. G. Zucker (Ed.). Institutional patterns and organizations: 3-22. Cambridge: Ballinger.

DiMaggio, P. J., \& Powell, W. W. 1983. The iron cage revisited: Institutional isomorphism and collective rationality in organizational fields. American Sociological Review, 48: 147-160.

Dixit, A. K. 2004. Lawlessness and economics: Alternative modes of governance. Princeton: Princeton University Press.

Frye, T. 2002. Capture or exchange? Business lobbying in Russia. Europe-Asia Studies, 54(7): 1017-1036.

Frye, T., \& Shleifer, A. 1997. The invisible hand and the grabbing hand. American Economic Review, 87: 354-358.

Goodman, D. S. G. 2007. Narratives of change: Culture and local economic development. In B. Krug \& H. Hendrischke (Eds.). The Chinese economy in the 21st century: Enterprise and business behaviour: 175-201. Cheltenham, UK: Edward Elgar.

Goodman, D. S. G. 2008. Why China has no new middle class: Cadres, managers and entrepreneurs. In D. S. G. Goodman (Ed.). The new rich in China: 23-37. London: Routledge.

Grabher, G., \& Stark, D. 1997. Organizing diversity: Evolutionary theory, network analysis and post socialism. Regional Studies, 31(5): 533-544.

Güth, W., \& Ockenfels, A. 2003. The coevolution of trust and institutions in anonymous and nonanonymous communities. In M. J. Holler, H. Kliemt, D. Schmidtchen, \& M. E. Streit (Eds.). The political economy of institutional evolution: 157-172. Tübingen, DE: J. C. B. Mohr.

Greif, A. 1989. Reputation and coalitions in medieval trade: Evidence on the Maghribi traders. Journal of Economic History, 49: 857-882.

Greif, A. 1997. Self-enforcing political system and economic growth: Late medieval Genoa. Working paper no. 97-037, Department of Economics, Stanford University, Palo Alto, California; CESifo (Center for Economic Studies and Ifo Institute for Economic Research), Munich, Germany.

Hall, P. A., \& Soskice, D. 2001. Varieties in capitalism: The institutional foundations of comparative advantage. New York: Oxford University Press.

Hamilton, G. G. 2006. Commerce and capitalism in Chinese societies. London: Routledge.

Hansman, H. 1996. The ownership of enterprise. Cambridge: Belknap.

Hendrischke, H. 2007. Networks as business networks. In B. Krug \& H. Hendrischke (Eds.). The Chinese economy in the 21st century: Enterprise and business behaviour: 202-222. Cheltenham, UK: Edward Elgar.

Hendrischke, H., \& Krug, B. 2010. China's informal sector: An institutional approach. Paper presented at the IACMR Conference, Shanghai, June 16-19.

Huang, Y. 1990. Web of interests and patterns of behaviour of Chinese local economic bureaucracies and enterprises during reforms. The China Quarterly, 123: 431-458.

Huang, Y. 2003. Selling China: Foreign direct investment during the reform era. Cambridge: Cambridge University Press.

Jiang, S., \& Hall, R. H. 1996. Local corporatism and rural enterprises in China's reform. Organization Studies, 17: 929-952. 
Keister, L. A. 2009. Organizational research on market transition: A sociological approach. Asia Pacific Journal of Management, 26(4): 719-742.

Kittsteiner, T., \& Ockenfels, A. 2006. Market design: A selective review. Zeitschrift für Betriebswirtschaft, 5: $121-143$.

Krug, B., \& Hendrischke, H. 2008. Framing China: Transformation and institutional change. Management and Organization Review, 4(1): 81-108.

Krug, B., Jacobs, G., \& Belschak, F. 2004. Social capital in China: The meaning of guanxi in Chinese business. In B. Krug (Ed.). China's rational entrepreneurs: The development of the new private business sector: 166-188. London: Routledge.

Krug, B., \& Polos, L. 2004. Emerging markets, entrepreneurship and uncertainty: The emergence of a private sector in China. In B. Krug (Ed.). China's rational entrepreneurs: The development of the new private business sector: 72-96. London: Routledge.

Kung, J. K. 1993. Organizational response to monitoring and sharing problems: The choice of reformation system in Chinese collective agriculture. Journal of Institutional and Theoretical Economics, 149(3): 597-590.

Laffont, J.-J. 2004. Management of public utilities in China. Annals of Economics and Finance, 5(2): 185210.

Li, P. P. 2005. The puzzle of China's township-village enterprises: The paradox of local corporatism in a dual track economic transition. Management and Organization Review, 1: 197-224.

March, J. G., Schultz, M., \& Zhou, X. 2000. The dynamics of rules: Change in written organizational rules. Palo Alto, CA: Stanford University Press.

Maskin, E. S. 2008. Mechanism design: How to implement social goals. American Economic Review, 98 (3): 567-576.

McNeil, I. 1978. Adjustment of long term economic relations under classical, neoclassical, and relational contract law. Northwestern Law Review, 72(6): 863-905.

Meyer, K. E., Estrin, S., Bhaumik, S. K., \& Peng, M. W. 2009. Institutions, resources, and entry strategies in emerging economies. Strategic Management Journal, 30: 61-80.

Milgrom, P. R., North, D. C., \& Weingast, B. R. 1990. The role of institutions in the revival of trade: The law merchant, private judges, and the champagne fairs. Economics and Politics, 2(1): 1-23.

National Bureau of Statistics of the People's Republic of China. 2008. Statistical yearbook of the People's republic of China: Section 17-14. Beijing: National Bureau of Statistics of the People's Republic of China.

Nee, V. 1989. A theory of market transition: From redistribution to markets in state socialism. American Sociological Review, 54: 663-681.

Nee, V. 2000. The role of the state in making a market economy. Journal of Institutional and Theoretical Economics, 156: 64-88.

Nee, V., \& Opper, S. 2010. Endogenous institutional change and dynamic capitalism. Sociologia del Lavoro. (forthcoming).

Nooteboom, B. 1996. Trust, opportunism and governance: A process and control model. Organization Studies, 17: 985-1010.

North, D. C. 2005. Understanding the process of economic change. Princeton: Princeton University Press.

Opper, S., Wong, S. M. L., \& Hu, R. 2002. Party power, markets and private power: Chinese communist party persistence in China's listed companies. The Future of Market Transition, 19: 103-136.

Peerenboom, R. 2005. What have we learned about law and development? Describing, predicting and assessing legal reforms in China. Michigan Journal of International Law, 27: 823-862.

Peng, M. W. 2003. Institutional transition and strategic choices. Academy of Management Review, 28(2): 275-296.

Peng, M. W., Sun, S. L., Pinkham, B., \& Chen, H. 2009. The institution-based view as a third leg for a strategy tripod. Academy of Management Perspectives, 23(3): 63-81.

Qian, Y., \& Weingast, B. R. 1997. Federalism as a commitment to preserving market incentives. Journal of Economic Perspectives, 11: 83-92.

Redding, G., \& Witt, M. A. 2009. China's business system and its future trajectory. Asia Pacific Journal of Management, 26(3): 381-399.

Richter, W. F., \& Wellisch, D. 1996. The provision of local public goods and factors in the presence of firm and household mobility. Journal of Public Economics, 60: 73-93.

Roth, A. E. 2007. What have we learned from market design?. NBER working paper series no. w13530, Washington, DC.

Selznick, P. 1996. Institutionalism "old" and "new. Administrative Science Quarterly, 41(2): 270-277.

Tyler, T. R. 1990. Why people obey the law. New Haven, CT and London: Yale University Press. 
Voigt, S. 2008. Are international merchants stupid? Their choice of law casts doubt on the legal origin theory. Journal of Empirical Legal Studies, 5: 1-20.

Walder, A. G. 1995. Local governments as industrial firms: An organizational analysis of China's transitional economy. American Journal of Sociology, 101: 263-301.

Walder, A. G. 2003. Elite opportunity in transitional economies. American Sociological Review, 68(6): 899-916.

Walter, C. E., \& Howie, F. J. T. 2006. Privatizing China: Inside china's stock markets. Singapore: John Wiley \& Sons.

Weingast, B. R. 1995. The economic role of political institutions: Market-preserving federalism and economic development. Journal of Law and Economic Organization, 11: 1-31.

Whitley, R. D. 1999. Divergent capitalism: The social construction and change of business systems. Oxford: Oxford University Press.

Whitley, R. D. 2007. Business systems and organizational capabilities: The institutional structuring of competitive competences. Oxford: Oxford University Press.

Williamson, O. E. 1985. The economic institutions of capitalism. Firms, markets, relational contracting. New York: Free.

Williamson, O. E. 1991. Comparative economic organization: The analysis of discrete structural alternative. Administrative Science Quarterly, 36: 269-296.

Wong, C. P. W., \& Chai, J. C. H. 2000. Fiscal reform and local industrialization. In J. C. H. Chai (Ed.). Reforms and opening up since 1979, vol. 3: 158-188. Cheltenham, UK: Edward Elgar.

World Bank. 1995. China: Macroeconomic stability in a decentralized economy. Washington, DC: The World Bank.

World Bank. 2007. World development indicators. Washington, DC: The World Bank.

Zhou, J. Q., \& Peng, M. W. 2010. Relational exchanges versus arm's-length transactions during institutional transitions. Asia Pacific Journal of Management, 27(3): 355-370.

Zhu, Z., \& Krug, B. 2007. China's emerging tax regime: Local tax farming and central tax bureaucracy. In B. Krug \& H. Hendrischke (Eds.). The Chinese economy in the 21st century: Enterprise and business behaviour: 145-174. Cheltenham, UK: Edward Elgar.

Barbara Krug ( $\mathrm{PhD}$, Saarland University) is professor for economics of governance in the Rotterdam School of Management (RSM) at Erasmus University of Rotterdam. Her most recent (edited) book is The Chinese Economy in the 21st Century: Enterprise and Business Behaviour (2007).

Hans Hendrischke (PhD, University of Bochum) is professor of Chinese political economy in the School of Social and Political Sciences at the University of Sydney, Australia. He is co-editor of The Chinese Economy in the 21st Century: Enterprise and Business Behaviour (2007). 